\title{
Isolation and molecular characterization of Malassezia pachydermatis from a cutaneous lesion in a California sea lion (Zalophus californianus)
}

\author{
Suzana Hađina ${ }^{1 *}$, Jadranko Boras ${ }^{2}$, Ingeborg Bata², Branimir Škrlin ${ }^{3}$,

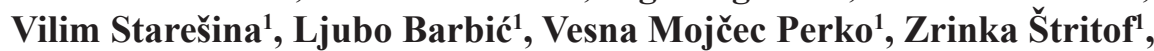 \\ Vladimir Stevanović ${ }^{1}$, Josipa Habuš ${ }^{1}$, Matko Perharić1, Zoran Milas ${ }^{1}$, \\ Nenad Turk ${ }^{1}$, and Ljiljana Pinter ${ }^{1}$
}

${ }^{l}$ Department of Microbiology and Infectious Diseases with Clinic, Faculty of Veterinary Medicine, University of Zagreb, Zagreb, Croatia

${ }^{2}$ Zagreb ZOO, Zagreb, Croatia

${ }^{3}$ Department of Radiology, Ultrasound Diagnostic and Physical Therapy, Faculty of Veterinary Medicine, University of Zagreb, Zagreb, Croatia

HAĐINA, S., J. BORAS, I. BATA, B. ŠKRLIN, V. STAREŠINA, LJ. BARBIĆ, V. MOJČE C PERKO, Z. ŠTRITOF, V. STEVANOVIĆ, J. HABUŠ, M. PERHARIĆ, Z. MILAS, N. TURK, LJ. PINTER: Isolation and molecular characterization of Malassezia pachydermatis from a cutaneous lesion in a California sea lion (Zalophus californianus). Vet. arhiv 89, 211-221, 2019.

\section{ABSTRACT}

Malassezia pachydermatis is an opportunistic yeast regularly isolated from the healthy and diseased skin of various animal species. There is scarcity of data about its presence on pinnipeds' skin and even less information about its pathogenicity in aquatic animals. In this study, a twenty-seven year old California sea lion (Zalophus californianus) was presented with alopecia and a cutaneous lesion on the right side of the trunk that had appeared in the spring, worsened through the summer and significantly improved in the winter months. Swab samples were obtained from the lesion and healthy skin sites (tail, posterior flippers, and trunk) and M. pachydermatis was recovered from all samples. The number of colonies grown from the lesion site was significantly higher than those cultured from the healthy skin. Employing the ITS-1 molecular marker we investigated whether there is any connection between sequence types of $M$. pachydermatis isolates recovered from the lesion, and those isolated from the healthy skin sites. Sequencing of the ITS-1 region of all isolates revealed a $99 \%$ match to the sequence of M. pachydermatis. In addition, all sequences belonged to the same genotype and there was no difference found between the isolates obtained from the lesion site and the healthy skin.

Key words: Malassezia pachydermatis; alopecia; cutaneous lesion; California sea lion (Zalophus californianus)

\footnotetext{
${ }^{*}$ Corresponding author:
}

Suzana Hađina, DVM, PhD, Assist. prof., Department of Microbiology and Infectious Diseases with Clinic, Faculty of Veterinary Medicine, University of Zagreb, Heinzelova 55, 10000 Zagreb, Croatia; Phone: +385 12390 200; Fax: +385 12390 207; E-mail: suzana.hadina@vef.hr 
S. Hađina et al.: Isolation and molecular characterization of Malassezia pachydermatis from a cutaneous lesion in a California sea lion

\section{Introduction}

M. pachydermatis is a yeast considered a member of the normal cutaneous microflora in domestic and wild animals (GUILLOT et al., 2010). Its presence as an opportunistic pathogen on the skin in general does not represent a threat to the animal's health. However, it is known that different underlying causes, such as prolonged antibiotic therapy, corticosteroid treatment, or endocrine disorders, could lead to yeast overgrowth, resulting in persistent skin infections in dogs (PLANT et al., 1992; MILLER et al., 2013). Wild animals in captivity live in an environment which mimics the natural habitat of their biological fauna. Any kind of disturbance of that balanced but vulnerable environment presents a stressful condition that could result in immunosuppression and the development of a clinical disease. In that aspect, pinnipeds are prone to develop various localized fungal infections or generalized infectious diseases (STOSKOPF, 2010). To date, there have been several reports of skin lesions in pinnipeds caused by different fungi, such as mold Fusarium solani (MONTALI et al., 1981), yeasts Candida albicans (DUNN et al., 1984), Rhodotorula mucilaginosa (ALVAREZ-PEREZ et al., 2010), and Cryptococcus albidus (McLELAND et al., 2012), or even dermatophytes such as Trichophyton mentagrophytes (POLLOCK et al., 2000), and Microsporum gypseum (SOS et al., 2013). In 1998, GUILLOT et al. described focal dermatitis in a California sea lion caused by $M$. pachydermatis, belonging to sequence type Id of LSU rRNA. In addition to molecular diagnostics, the etiology was confirmed by fungal culture and histopathological methods, coupled with a good response to the localized antifungal therapy. A few years later, a research group from Japan reported a case of generalized dermatitis in a South American sea lion, caused by the same type of yeast identified via the fungal culture on dermatophyte test medium, with their typical growth observed on the Sabouraud-dextrose agar, without lipid supplementation, and comparison of the grown isolates with canine isolates using the freeze-etch electron microscopy (NAKAGAKI et al., 2000). A study by POLLOCK et al. (2000) reported ten episodes of fungal dermatitis in seals within a two-year period. Their diagnoses were based on skin scrapings, swab and hair cultures, or biopsy. Besides Trichophyton mentagrophytes and Yarrowia (Candida) lipolytica, the authors isolated numerous colonies of Malassezia sp. from an erythematous and ulcerated lesion located on the flipper of a California sea lion. The same yeast species was also isolated from different tissue samples from two gray seals and two harbor seals, although they were lower in number. In other animal species, (e.g. dogs), different molecular typing methods were applied in order to assess the possible presence of diverse genetic types of $M$. pachydermatis at different body sites, their distribution and relationship to the clinically affected skin areas (CAFARCHIA et al., 2007; MACHADO et al., 2010; HAN et al., 2013; PUIG et al., 2016). The most commonly used are sequence analyses of large subunits (LSU), internal transcribed spacer (ITS-1) and intergenic spacer 1 (IGS-1) regions of 
ribosomal DNA, together with two protein encoding genes, chitin synthase 2 (CHS-2) and $\beta$ tubulin. Different studies have reported various frequencies of isolation of distinct genetic types of $M$. pachydermatis from healthy and diseased skin sites demonstrating its high genetic diversity (CASTELLA et al., 2005; SUGITA et al., 2005; CAFARCHIA et al., 2008; MACHADO et al., 2010; HAN et al., 2013; PUIG et al., 2016). However, the potential pathogenic features of diverse genotypes of M. pachydermatis have still not been completely clarified.

The aim of this study was to identify and molecularly characterize M. pachydermatis isolates obtained from a cutaneous lesion and the healthy skin of a California sea lion. In addition, employing the ITS- 1 molecular marker we further investigated the possible connection between the sequence types of $M$. pachydermatis recovered from the lesion and the one isolated from the healthy skin sites.

\section{Materials and methods}

Sampling. Swab samples were taken from the cutaneous lesion (Fig. 1) and the healthy skin site of the trunk, tail and posterior flippers (left and right).
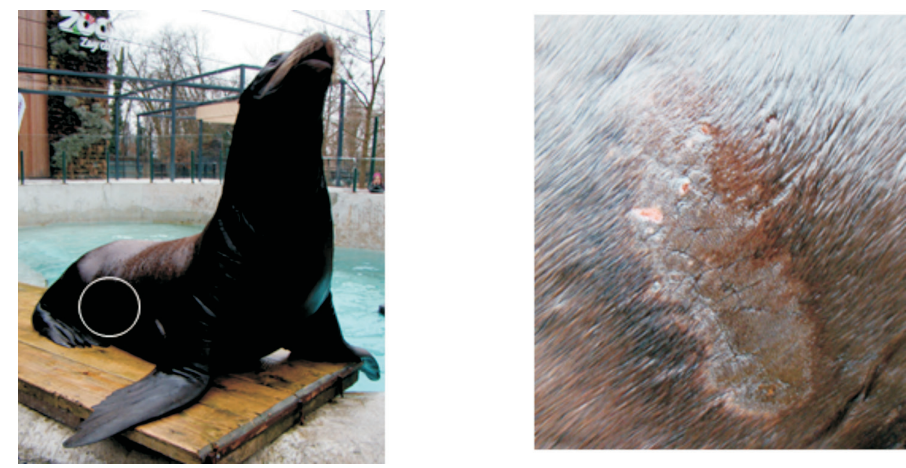

Fig. 1. Alopecia and a cutaneous lesion on the right side of the trunk of the captive California sea lion. The photo shows an irregularly elongated, ovoid, hairless brown-gray area with a few multifocal erosions.

Since the animal was not trained to allow manipulation, no samples from the external ear canal were taken. Before the pool was cleaned and the water changed, swabs from the pool walls and water (four samples in total) were taken and processed for the Malassezia culture. Swabs were immediately inoculated onto modified Dixon agar ( $36 \mathrm{~g}$ malt extract, $10 \mathrm{~g}$ peptone, $20 \mathrm{~g}$ desiccated ox-bile, $10 \mathrm{~mL}$ Tween $40,2 \mathrm{~mL}$ glycerol, $2 \mathrm{~mL}$ oleic acid, $15 \mathrm{~g}$ agar, $1 \mathrm{~L}$ demineralized water, $(\mathrm{pH} 6.0)$ with the addition of $0.5 \mathrm{~g}$ chloramphenicol, $0.5 \mathrm{~g}$ cycloheximide) and incubated at $32{ }^{\circ} \mathrm{C}$ for 14 days. Identification of the yeast 
colonies was based on the morphological and microscopic characteristics, as previously described (GUÉHO -KELLERMANN et al., 2010). Lipid dependency was determined by plating yeast colonies on Sabouraud dextrose agar (SDA) (Bio-Rad, USA). Furthermore, biochemical characterization was performed using both an urease test and a $\beta$-glucosidase test. In order to rule out possible involvement of bacteria in the pathogenesis of this lesion, swabs were plated on Columbia agar, with the addition of 5\% sheep blood and McConkey agar (Oxoid, UK), and incubated at $37^{\circ} \mathrm{C}$ for 24 hours.

DNA extraction and molecular identification. Three-day old yeast colonies were scraped from the plate, suspended in zymolyase buffer and homogenized using $0.5 \mathrm{~g}$ of glass beads (150-212 $\mu \mathrm{m}$; Sigma). After adding zymolyase enzyme (Zymo Research, USA), genomic DNA was isolated using an Invitrogen PureLink Genomic DNA Mini Kit (Invitrogen, USA). The extracted DNA was stored at $-20^{\circ} \mathrm{C}$ until molecular identification. The ITS-1 region was amplified using 18SF1 (5'-AGGTTTCCGTAGGTGAACCT-3') and 5.8SR1 (5'-TTCGCTGCGTTCTTCATCGA-3') primers, as previously described (CAFARCHIA et al., 2007). In short, amplification was performed using the following PCR cycles: one cycle of activation and denaturation at $94{ }^{\circ} \mathrm{C}$ for $12 \mathrm{~min}$, followed by 35 cycles of $94{ }^{\circ} \mathrm{C}$ for $30 \mathrm{~s}, 60^{\circ} \mathrm{C}$ for $15 \mathrm{~s}$, at $72{ }^{\circ} \mathrm{C}$ for $15 \mathrm{~s}$, and one cycle of final extension at $72{ }^{\circ} \mathrm{C}$ for $7 \mathrm{~min}$, ending with cooling at $4{ }^{\circ} \mathrm{C}$. PCR products were visualized on $1 \%$ agarose and sent to Macrogen (Amsterdam, Netherlands) for purification and sequencing from both strands. Nucleotide sequences were searched using BLAST, edited and analyzed using CHROMAS, ver. 2.6.2 and BioEdit ver. 7.0.5 software. Sequence alignment was performed with Clustal X ver. 2.0 (LARKIN et al., 2007). Aligned nucleotide sequences were compared with sequences of $M$. pachydermatis recovered from different animal species and deposited in the GeneBank ${ }^{\mathrm{TM}}$ database (GenBank accession no. AY743637, KU313709, KU313710, KU313711, KU313712, KU313713, KU313714, KU313715, KU313716, KU313717, KU313718) as previously described (PUIG et al., 2016). For the tree construction, sequences of M. furfur CBS 1878 (Ac. No. AY743634) and CBS 7019 (Ac. No. AY743635), M. obtusa CBS7876 (Ac. No. AY387137) and M. japonica CBS9431 (Ac. No. AB105199) were used. The sequence of Cryptococcus neoformans CBS 132 (Ac. No. KC530795) was selected as an outgroup. Phylogenetic analysis was performed using MEGA 7 software (KUMAR et al., 2016).

\section{Results}

Malassezia isolation. Colonies grown on the Dixon media were round, butyrous, convex and a few millimeters in diameter within the zone of precipitation (Fig. 2a). Microscopic examination showed ellipsoidal cell morphology (Fig. 2b). Identified Malassezia yeast colonies grew on SDA without the addition of lipids. Moreover, positive urease and $\beta$-glucosidase tests were confirmed. Swabs obtained from the pinniped's 
pool and water did not yield Malassezia growth. Furthermore, no bacterial growth was observed in samples obtained from the lesion with alopecia, even after prolonged incubation for an additional 24 hours. The fungal culture of the samples obtained from healthy skin sites yielded just a few Malassezia colonies; one colony from the tail, nine from the right flipper and seven from the left flipper, respectively. In comparison, samples from the cutaneous lesion yielded more than 100 colonies per plate.

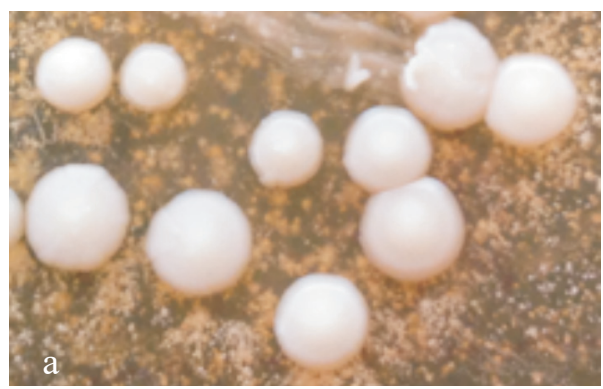

Fig. 2a. Malassezia pachydermatis colonies grown on a plate sampled from the cutaneous lesion

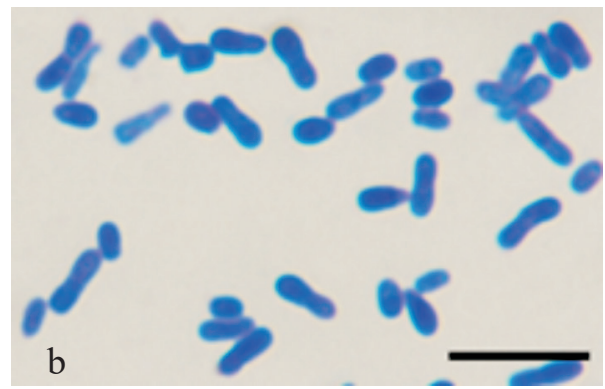

Fig. 2b. Microscopic appearance of yeast organisms (Diff Quik staining, scale bar $=10$ $\mu \mathrm{m}, \times 2000)$

Molecular identification and sequencing. Using ITS-1 primers, the sequence of $\sim 280$ bp size was successfully amplified. All seven sequences showed $99 \%$ identity match to the ITS-1 region of M. pachydermatis strain CBS 1885 using BLAST. Phylogenetic analyses showed that the sequences of all the isolates grouped in one clade together with the sequences of MA 107 originating from the goat, MA 312 from the cat, and MA 1382 and MA 280 from the dog described by PUIG et al. (2016) (Fig. 3). 
S. Hađina et al.: Isolation and molecular characterization of Malassezia pachydermatis from a cutaneous lesion in a California sea lion

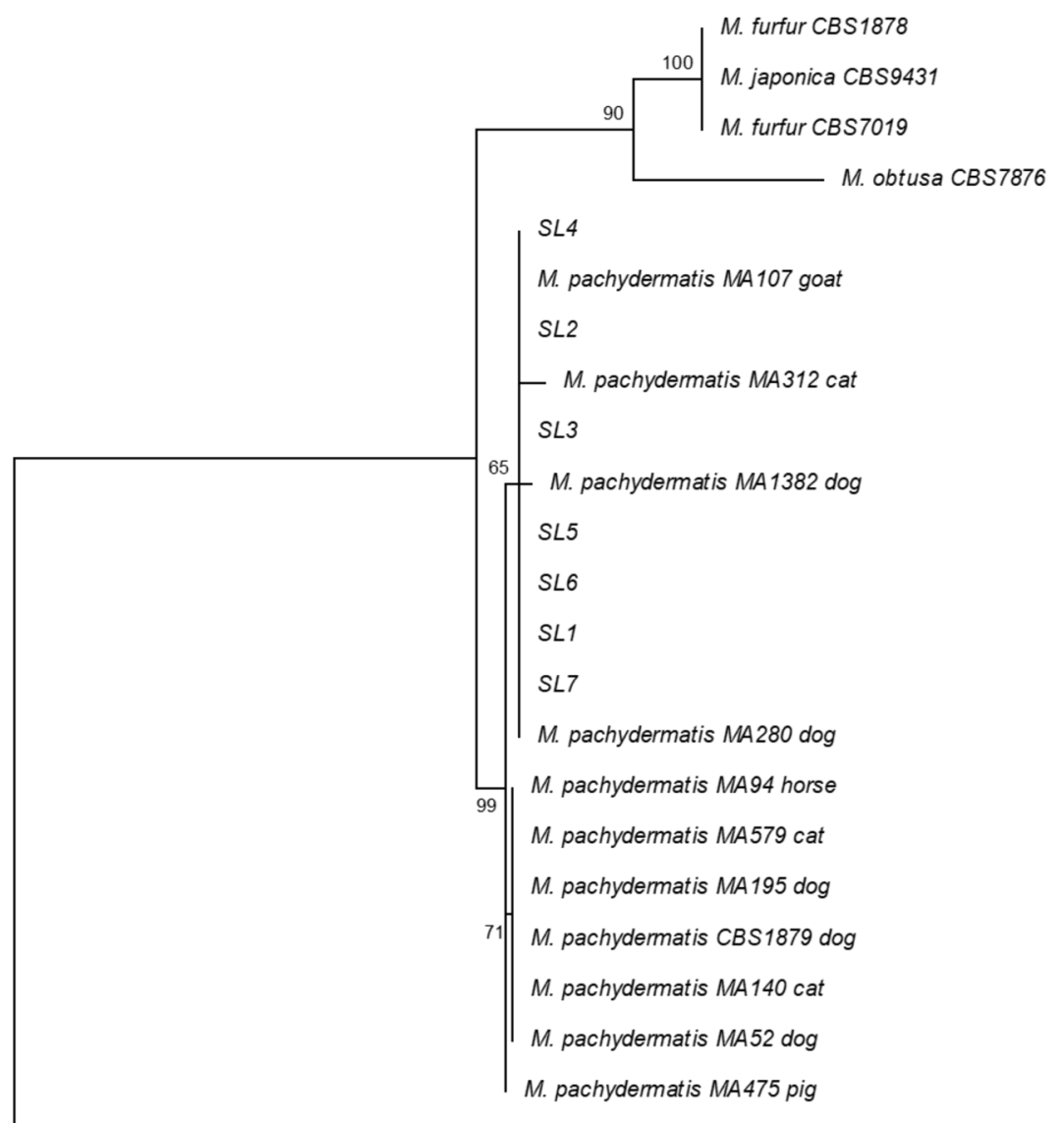

Cryptococcus neoformans CBS132

0.10

Fig. 3. Molecular phylogenetic analysis of the ITS-1 sequence by maximum likelihood method was analyzed using the Kimura 2-parameter model (KIMURA, 1980). Bootstrap values $>60 \%$ in 1000 replications are shown at the nodes. The tree is rooted with Cryptococcus neoformans. The scale bar represent the number of nucleotide substitutions per site. Sea lion isolates are marked as SL.

\section{Discussion}

In most animal species, Malassezia dermatitis develops as a result of an overgrowth of this opportunistic yeast that is considered to be a member of normal skin microflora. Disturbance of various skin microenvironmental factors, including body temperature, 
humidity and skin $\mathrm{pH}$, together with exposure to UV lights and inadequate immune response of the host are the main factors in the development of clinical signs of the dermatomycosis caused by this agent (MILLER et al., 2013). There is a notable scarcity of data reporting the occurrence of Malassezia yeast on pinniped skin and even less about its pathogenicity in aquatic animals. The first report of focal dermatitis caused by M. pachydermatis in a California sea lion was described by GUILLOT et al. (1998), followed by another report of dermatitis in a South American sea lion (NAKAGAKI et al., 2000). In this study, a twenty-seven year old California sea lion was presented with alopecia and a cutaneous lesion characterized by a few multifocal erosions on the right side of the trunk. The lesion appeared in the spring, worsened throughout the summer and improved during the winter months. Dermatological changes started to recur each year indicating that it was a self-limiting process to a certain extent. Treatment of the alopecic area during summer months included topical therapy with a chlorhexidine antiseptic for the skin $\left(\mathrm{PLIVA}^{\circledR}\right.$ sept, Pliva) that resulted in improvement of the skin lesion, with complete resolution of the erosions and the beginning of hair regrowth during the winter months. A fungal culture of swab samples taken in the spring, demonstrated only the limited presence of $M$. pachydermatis on the healthy skin from the trunk, flippers, and tail, but a significantly higher number of colonies were isolated from the lesion site on the California sea lion. The large number of M. pachydermatis colonies recovered from the lesion indicated that there must be some predisposing factors present, so this opportunistic yeast could overgrow and cause these changes. Different environmental factors that promote fungal overgrowth, such as an increase in water temperature in the pool and the outside temperatures during the summer, or high chlorine concentrations in the swimming pool, could contribute to the development of different fungal infections, or worsen the clinical signs of existing skin problems in pinnipeds (MONTALI et al., 1981; SOS et al., 2013). All the aforementioned could be an explanation of the improvement in clinical signs during the winter months and the worsening of the symptoms in the summer months observed in this study.

Several metagenomic studies have reported the presence of the Malassezia genome on the surface of soil nematodes (RENKER et al., 2003; ELHADY et al., 2017), marine sponges, seawater (GAO, 2003) and corals (AMEND at al., 2012). In this study, sampling the environment as a possible source of the Malassezia yeast, and culturing of the swabs from the pool walls and water samples did not yield any Malassezia growth. In contrast, in a previous study that described generalized dermatitis in a South American sea lion, the authors successfully isolated M. pachydermatis from the pool water on a dermatophyte test medium (NAKAGAKI et al., 2000).

There is a study that genetically characterized M. pachydermatis isolated from a California sea lion, using LSU of ribosomal RNA. The isolated species belonged to sequence type Id, as did previously detected genotype isolates from dogs (GUILLOT et al., 1997; GUILLOT et al., 1998). According to the available literature, most genetic studies 
involving $M$. pachydermatis were related to dogs. One study found that some genotypes of this yeast were predominantly associated with skin lesions in dogs, also demonstrating that the ITS-1 region is variable and useful for distinguishing different genotypes and subgenotypes of $M$. pachydermatis species (CAFARCHIA et al., 2008). Using the same genetic marker, MACHADO et al. (2010) did not find a connection between the presence of the particular M. pachydermatis genotype and dermatitis in dogs. In another study a multi-sequence alignment approach resulted in identification of different sequence types, depending on the analyzed region, LSU, ITS, CHS- 2 or $\beta$-tubulin gene. The multilocus tree showed that some genetic types of $M$. pachydermatis could be associated with the animal species from which they were isolated, but not with the pathological changes they caused (PUIG et al., 2016).

The isolates obtained from the sea lion in this study were grouped in one clade together with strains of $M$. pachydermatis from a healthy goat, and the cats and dogs with otitis described by PUIG et al. (2016). In addition, no difference in the fungal genotypes isolated from the lesion site and intact areas of the skin were found, as reported in a previous study on dogs (MACHADO et al., 2010). From all the current scientific data, the genetic diversity of $M$. pachydermatis still requires further research to contribute to a better understanding of the ecology of this yeast.

\section{Conclusion}

The paucity of Malassezia yeast data and their potential genetic host diversity in pinnipeds prompted this molecular investigation of the fungal strains obtained from an isolated case of a captive sea lion that presented with recurrent localized dermatomycosis. A significantly higher number of $M$. pachydermatis colonies were isolated from the cutaneous lesion in comparison to the number of isolates recovered from the intact areas of skin. However, molecular characterization revealed no differences between the strain isolates. Only a few previous studies have reported $M$. pachydermatis as the cause of fungal dermatitis in pinnipeds. Its role in the pathogenesis of skin lesions and the association between a certain genotype and different dermatological disorders in animals still remains ambiguous and warrants further investigation.

\section{References}

ALVAREZ-PEREZ, S., A. MATEOS, L. DOMINGUEZ, E. MARTINEZ-NEVADO, J. L. BLANCO, M. E. GARCIA (2010): Isolation of Rhodotorula mucilaginosa from skin lesions in a Southern sea lion (Otaria flavescens): a case report. Vet. Med. (Praha). 55, 297-301.

DOI: 10.17221/2988-VETMED

AMEND, A. S., D. J. BARSHIS, T. A. OLIVER (2012): Coral-associated marine fungi form novel lineages and heterogeneous assemblages. ISME J. 6, 1291-1301.

DOI: $10.1038 /$ ismej.2011.193 
S. Hađina et al.: Isolation and molecular characterization of Malassezia pachydermatis from a cutaneous lesion in a California sea lion

CAFARCHIA, C., M. STEFANIA LATROFA, G. TESTINI, A. PARISI, J. GUILLOT, R. B. GASSER, D. OTRANTO (2007): Molecular characterization of Malassezia isolates from dogs using three distinct genetic markers in nuclear DNA. Mol. Cell. Probes. 21, 229-238.

DOI: $10.1016 /$ j.mcp.2007.01.002

CAFARCHIA, C., R. B. GASSER, M. S. LATROFA, A. PARISI, B. E. CAMPBELL, D. OTRANTO (2008): Genetic variants of Malassezia pachydermatis from canine skin: body distribution and phospholipase activity. FEMS Yeast Res. 8, 451-459.

DOI: 10.1111/j.1567-1364.2008.00358.x

CASTELlA, G., J. J. HERNÀNDEZ, F. J. CABANES (2005): Genetic typing of Malassezia pachydermatis from different domestic animals. Vet. Microbiol. 108, 291-296.

DOI: 10.1016/j.vetmic.2005.04.016

DUNN, J. L., J. D. BUCK, S. SPOTTE (1984): Candidiasis in captive pinnipeds. J. Am. Vet. Med. Assoc. 185, 1328-1330.

ELHADY, A., A. GINE, O. TOPALOVIC, S. JACQUIOD, S. J. SORENSEN, F. J. SORRIBAS, H. HEUER (2017): Microbiomes associated with infective stages of root-knot and lesion nematodes in soil. PloS one. 12, e0177145.

DOI: 10.1371/journal.pone.0177145

GAO, Z., L. BINGLIN, Z. CHENGCHAO, W. GUANGYI (2003): Molecular detection of fungal communities in the Hawaiian marine sponges Suberites zeteki and Mycale armata. Appl. Environ. Microbiol. 74, 6091-6101.

DOI: 10.1128/AEM.01315-08.

GUÉHO-KELLERMANN, E., T. BOEKHOUT, D. BEGEROW (2010): Biodiversity, phylogeny and ultrastructure. In: Malassezia and the Skin. Science and Clinical Practice. (Boekhout, T., E. Guého-Kellermann, P. Mayser, A. Velegraki, Eds.). Springer Verlag, Heidelberg, Dordrecht, London, New York, pp. 17-63.

DOI: 10.1007/978-3-642-03616-3_2

GUILLOT, J., E. GUÉHO, G. CHÉVRIER, R. CHERMETTE (1997): Epidemiological analysis of Malassezia pachydermatis isolates by partial sequencing of the large subunit ribosomal RNA. Res. Vet. Sci. 62, 22-25.

DOI: 10.1016/S0034-5288(97)90174-0

GUILlot, J., T. PETIT, F. DEGORCE-RUBIAlES, E. GUÉHO, R. CHERMETTE (1998): Dermatitis caused by Malassezia pachydermatis in a California sea lion (Zalophus californianus). Vet. Rec. 142, 311-312.

DOI: $10.1136 / v r .142 .12 .311$

GUILlOT, J., S. HAĐINA, J. CABAÑES (2010): Animal epidemiology. In: Malassezia and the Skin. (Boekhout, T., E. Guého-Kellermann, P. Mayser, A. Velegraki, Eds.). Springer Verlag, Heidelberg, Dordrecht, London, New York, pp. 94-119.

Vet. arhiv 89 (2), 211-221, 2019 
S. Hađina et al.: Isolation and molecular characterization of Malassezia pachydermatis from a cutaneous lesion in a California sea lion

HAN, S. H., T. H. CHUNG, E. H. NAM, S. H. PARK, C. Y. HWANG (2013): Molecular analysis of Malassezia pachydermatis isolated from canine skin and ear in Korea. Med. Mycol. 51, 396-404.

DOI: $10.3109 / 13693786.2012 .740575$

KIMURA, M. (1980): A simple method for estimating evolutionary rates of base substitutions through comparative studies of nucleotide sequences. J. Mol. Evol. 16, 111-120.

DOI: $10.1007 / \mathrm{BF} 01731581$

KUMAR, S., G. STECHER, K. TAMURA (2016): MEGA7: Molecular evolutionary genetics analysis version 7.0 for bigger datasets. Mol. Biol. Evol. 33, 1870-1874.

DOI: $10.1093 / \mathrm{molbev} / \mathrm{msw} 054$

LARKIN, M. A., G. BLACKSHIELDS, N. P. BROWN, R. CHENNA, P. A. McGETTIGAN, H. McWILLIAM, F. VALENTIN, I. M. WALLACE, A. WILM, R. LOPEZ, J. D. THOMPSON, T. J. GIBSON, D. G. HIGGINS (2007): Clustal W and Clustal X version 2.0. Bioinformatics 23, 2947-2948.

DOI: 10.1093/bioinformatics/btm404

MACHADO, M. L. S., C. CAFARCHIA, D. OTRANTO, R. R. FERREIRA, S. P. BIANCHI, M. S. LATROFA, A. PARISI, L. FERREIRO (2010): Genetic variability and phospholipase production of Malassezia pachydermatis isolated from dogs with diverse grades of skin lesions. Med. Mycol. 48, 889-892.

DOI: $10.3109 / 13693780903532080$

McLELAND, S., C. DUNCAN, T. SPRAKER, E. WHEELER, S. R. LOCKHART, F. GULLAND (2012): Cryptococcus albidus infection in a California sea lion (Zalophus californianus). J. Wildl. Dis. 48, 1030-1034.

DOI: $10.7589 / 2011-08-226$

MILLER, W. H., C. E. GRIFFIN, K. L. CAMPBELL (2013): Malassezia dermatitis In: Muller and Kirk's Small Animal Dermatology. $7^{\text {th }}$ ed. (Miller, W. H., C. E. Griffin, K. L. Campbell, Eds.). Elsevier, St. Louis, pp. 243-249.

MONTALI, R. J., M. BUSH, J. D. STRANDBERG, D. L. JANSSEN, D. J. BONESS, J. C. WHITLA (1981): Cyclic dermatitis associated with Fusarium sp. infection in pinnipeds. J. Am. Vet. Med. Assoc. 179, 1198-1202.

NAKAGAKI, K., K. HATA, E. IWATA, K. TAKEO (2000): Malassezia pachydermatis isolated from a South American sea lion (Otaria byronia) with dermatitis. J. Vet. Med. Sci. 62, 901-903.

DOI: $10.1292 /$ jvms.62.901

PLANT, J., W. ROSENKRANTZ, C. GRIFFIN (1992): Factors associated with and prevalence of high Malassezia pachydermatis numbers on dog skin. J. Am. Vet. Med. Assoc. 201, 879-882.

POLLOCK, C. G., B. ROHRBACH, E. C. RAMSAY (2000): Fungal dermatitis in captive pinnipeds. J. Zoo. Wildl. Med. 31, 374-378.

DOI: 10.1638/1042-7260(2000)031[0374:FDICP]2.0.CO;2 
S. Hađina et al.: Isolation and molecular characterization of Malassezia pachydermatis from a cutaneous lesion in a California sea lion

PUIG, L., G. CASTELLÁ, F. J. CABAÑES (2016): Cryptic diversity of Malassezia pachydermatis from healthy and diseased domestic animals. Mycopathologia 181, 681-688.

DOI: $10.1007 / \mathrm{s} 11046-016-0026-3$

RENKER, C., J. ALPHEI, F. BUSCOT (2003): Soil nematodes associated with mammal pathogenic fungal genus Malassezia (Basidiomycota: Ustilaginomycetes) in Central European Forests. Biol. Fert. Soils. 37, 70-72.

DOI: $10.1007 / \mathrm{s} 00374-002-0556-3$

SOS, E., V. MOLNAR, Z. LAJOS, V. KOROKNAI, J. GAL (2013): Successfully treated dermatomycosis in California sea lions (Zalophus californianus). J. Zoo. Wildl. Med. 44, $462-465$.

DOI: $10.1638 / 2011-0275 R 1.1$

STOSKOPF, M. K. (2010): Marine mammals. In: The Merck Veterinary Manual, $10^{\text {th }}$ ed. (Kahn, C. M., S. Line, Eds.). Whitehousestation, NJ, USA, Merck \& Co., Inc. pp. 1661-1675.

SUGITA, T., K. TAKEO, K. HAMA, E. VIRTUDAZO, M. TAKASHIMA, A. NISHIKAWA, J. KUCSERA, J. DOROGI, S. KOMORI, K. NAKAGAKI, A. VOLLEKOVA, E. SLAVIKOVA, V. FARKAS (2005): DNA sequence diversity of intergenic spacer I region in the non-lipiddependent species Malassezia pachydermatis isolated from animals. Med. Mycol. 43, 21-26.

DOI: $10.1080 / 1369378042000193185$

Received: 1 December 2017

Accepted: 10 April 2018

\section{HAĐINA, S., J. BORAS, I. BATA, B. ŠKRLIN, V. STAREŠINA, LJ. BARBIĆ, V. MOJČEC PERKO, Z. ŚTRITOF, V. STEVANOVIĆ, J. HABUŠ, M. PERHARIĆ, Z. MILAS, N. TURK, LJ. PINTER: Izdvajanje i molekularna karakterizacija gljivice Malassezia pachydermatis podrijetlom s kožne promjene kalifornijskog morskog lava (Zalophus californianus). Vet. arhiv 89, 211-221, 2019. \\ SAŽETAK}

Malassezia pachydermatis jest gljivica slična kvascima, koja se može izdvojiti iz zdrave kože, ali i promjena na koži različitih životinjskih vrsta. Vrlo je malo podataka o njezinoj prisutnosti na koži perajara, a još manje o njezinu patogenom potencijalu kod životinja koje žive u vodi. U ovom je istraživanju opisano izdvajanje gljivice $M$. pachydermatis s kožne promjene smještene na desnoj strani trupa kalifornijskoga morskog lava (Zalophus californianus). Bezdlačno područje i kožne promjene pojavile bi se u proljeće, proširile tijekom ljetnih mjeseci, da bi zimi došlo do znatnog poboljšanja. Uzimanjem obrisaka s promijenjenog i nepromijenjenih područja kože (rep, stražnje peraje i trup) izdvojena je gljivica $M$. pachydermatis. Broj naraslih kolonija iz obrisaka uzetih s promijenjenog dijela kože bio je znatno veći u odnosu na broj kolonija naraslih sa zdravih dijelova. Uporabom ITS-1 molekularnog markera željela se ustanoviti povezanost između određenoga genskog tipa izdvojene gljivice $M$. pachydermatis i mjesta izdvajanja. Koristeći se molekularnim markerom ITS-1, određivanjem slijeda nukleotida, ustanovljena je podudarnost svih izdvojenih sojeva s gljivicom $M$. pachydermatis od $99 \%$. Osim toga svi su sojevi pripadali istome genskom tipu te nije ustanovljena razlika u genotipu sojeva izdvojenih iz kožne promjene i onih izdvojenih s vidljivo nepromijenjenih mjesta.

Ključne riječi: Malassezia pachydermatis; bezdlačno područje; kožna promjena; kalifornijski morski lav (Zalophus californianus) 
